\title{
Galactose Metabolism in Suckling and Adult Isolated Rat Hepatocytes
}

\author{
SHIRLEY ROGERS, MARTA GUERRA, AND STANTON SEGAL ${ }^{(40)}$ \\ Division of Biochemical Development and Molecular Diseases, Children's Hospital of Philadelphia, Departments of \\ Medicine and Pediatrics, University of Pennsylvania School of Medicine, Philadelphia, Pennsylvania, USA
}

\begin{abstract}
Summary
The metabolism of galactose during the postnatal developmental period has been examined in isolated parenchymal cells of livers from fasted rats aged $7,14,21,28$, and 42 days, by measuring the disappearance of 1 and $4 \mathrm{mM} 1-\left[{ }^{14} \mathrm{C} \mid g a l a c t o s e\right.$ from the incubation media as well as $\left[{ }^{14} \mathrm{C}\right.$ lgalactose conversion to $\left[{ }^{14} \mathrm{C}\right.$ lglucose and ${ }^{14} \mathrm{C} \mid l a c t a t e$ and oxidation to $\left[{ }^{14} \mathrm{CO}_{2}\right]$. Cells from 7- and 14-day-old suckling animals consistently utilized galactose more rapidly (4 times greater) than those of adult. Hepatocytes of suckling rats also converted greater amounts of galactose to glucose and oxidized galactose 2-3 times faster than the adult. The conversion to glucose by suckling cells occurred with minor recycling of labeled C-1 galactose to $C-6$ of glucose. A comparison with $\left[1-{ }^{14} \mathrm{C}\right]$ glucose as substrate showed that oxidative rates by the young cells were 3 times faster for galactose than for glucose. This was not due to the presence of a direct galactose oxidative pathway as assessed by the $\left[{ }^{14} \mathrm{CO}_{2}\right]$ yield from $\mathrm{C}-1$ and $\mathrm{C}-2$ labeled galactose. Incubation of hepatocytes with galactose appeared to augment the production of glucose from endogenous precursors, 33 nmoles/mg cells in 30 min. The enhanced glucose output from endogenous sources in isolated suckling hepatocytes incubated with galactose contrasts with the sugar's suppression of glucose output observed in isolated perfused liver even though galactose metabolism in both preparations are similarly greater in the suckling than in the adult.
\end{abstract}

\section{Abbreviations}

KRB, Krebs-Ringer bicarbonate

KRB-A, Krebs-Ringer bicarbonate containing 3\% albumin LDH, L-lactic dehydrogenase

In the young mammal, galactose is an important dietary carbohydrate. Because the liver is the major organ involved in the metabolism of galactose (34), our laboratory has focused on the mechanism whereby this hepatic process occurs. Past developmental analyses of rat liver galactokinase (10), galactose-1-phosphate uridyltransferase (5), and uridine diphosphogalactose-4epimerase (9) (the major enzymes of galactose disposition), indicated their specific activity to be maximal during the suckling period. In order to more precisely learn the details of galactose uptake and conversion to glucose by suckling rat livers, we have recently utilized the isolated liver perfusion technique $(3,22)$. A comparison of isolated perfused livers of suckling and adult rats revealed that the liver of the suckling rat not only took up more galactose from the perfusate than the adult, but put out proportionately larger amounts of glucose (2). Indeed, over $80 \%$ of perfused galactose was converted to glucose by livers of suckling animals (3).

Whereas the isolated perfused liver has been extensively used as a physiologic model system to study metabolic processes (13, $15,39)$, isolated hepatocytes have become a tool used to promote evaluation at the cellular level and to augment results obtained with the intact organ system $(1,19,38)$ : The use of the hepatocyte preparation eliminates the metabolic contribution of other hepatic cellular elements, facilitates easy manipulation of experimental conditions and provides ready determination of oxidative metabolic rates, which could not be done in our own perfusion experiments inasmuch as the perfusion apparatus did not permit $\mathrm{CO}_{2}$ collection. For these reasons, the differences in galactose uptake and glucose output observed in suckling and adult galactose perfused livers $(2,3)$ have been more extensively studied in isolated hepatocytes to determine other metabolic fates, especially galactose oxidation by cells from young and adult livers. Our results form the basis of this report.

\section{EXPERIMENTAL}

Animals. Adult, 42-day-old, Sprague-Dawley male rats weighing 135-150 g and 7-, 14-, and 28-day-old, non-litter mates were the animals used. At the age of 5 days, litters were randomly mixed and culled to nine pups each. Pups were weaned and separated according to sex at 21 days. Animals were fasted for 18 $h$ with free access to water before surgery. Young animals were removed from the mother and placed in a warm, dark area for fasting. The anesthesia was $50 \mathrm{mg} / \mathrm{kg}$ of sodium pentobarbital injected intraperitoneally.

Chemicals. Collagenase was obtained from Worthington Biochemical Corporation, Freehold, NJ. Glucose-free galactose was a product of Sigma, St. Louis, MO. D- $\left[1-{ }^{14} \mathrm{C}\right]$ galactose, D- $\left[1-{ }^{14} \mathrm{C}\right]$ glucose and $\mathrm{D}-\left[2-{ }^{14} \mathrm{C}\right]$ glucose $(50 \mathrm{mCi} / \mathrm{mM})$ were purchased from Amersham Corp., Arlington Heights, IL. Radiolabeled glactose did not contain glucose as a contaminant and was used without additional purification. $\mathrm{D}-\left[2-{ }^{14} \mathrm{C}\right]$ galactose $(0.55 \mathrm{mCi} / \mathrm{mM})$ was supplied by Calbiochem, Los Angeles, CA. Bovine serum albumin, Fraction V came from Miles Laboratories, Elkhart, IN, hydroxide of hyamine-10x from Packard, Downers Grover, IL and a glucose analysis kit was supplied by Biodynamics, Brookfield, CT. Whatman $3 \mathrm{~mm}$ paper and all other chemicals of the highest quality available were obtained through Fisher Scientific, King of Prussia, PA.

Isolated hepatocyte preparation. Liver cells were isolated by the procedure of Berry and Friend (4) with some modifications by Seglen (28) such as the addition of EGTA to $\mathrm{Ca}^{2+}$-free buffer for the non-recirculating perfusion phase and the omission of $\mathrm{Mg}^{2+}$ from the media for the recirculating phase. Warmed, oxygenated Krebs-Ringer bicardonate buffer (KRB), pH 7.4 was the basic perfusion and incubation media used for all experiments.

Hepatocytes were isolated from livers of fasted rats aged 7, 14, 21,28 , and 42 days. To minimize biologic variations due to individual differences, each batch of hepatocytes was prepared from tissue of more than one animal. Livers of two to three adult or three to four young rats were simultaneously perfused on a Mortimore apparatus (20) utilizing the surgical techniques described previously (2). Because livers of younger animals are smaller and more fragile than the adult, volumes and perfusion rates varied according to the size and lability of livers at various 
developmental stages. Adult rat livers were perfused with $100 \mathrm{ml}$ of $\mathrm{Ca}^{2+}$-free $\mathrm{KRB}$ containing $0.5 \mathrm{mM} \mathrm{EGTA}$ at $12.5 \mathrm{ml} / \mathrm{min}$; livers of animals at 21- and 28-days were perfused with $50 \mathrm{ml}$ at $5 \mathrm{ml} / \mathrm{min}, 14-$ day at $4 \mathrm{ml} / \mathrm{min}$ and 7 -day at $2 \mathrm{ml} / \mathrm{min}$. At the end of the non-recirculating period when the media flasks were nearly empty, $\mathrm{Mg}^{2+}$-free $\mathrm{KRB}$ containing $0.05 \%$ collagenase was added. The perfusion was continued in a recirculating mode $20-25 \mathrm{~min}$ for adult livers or until the livers had swelled, softened and started to 'leak.' Fragile, immature livers leak sooner than adult livers, usually after less than 15 min of recirculating collagenase media. Livers were combined, minced in collagenase media and digested an additional $15 \mathrm{~min}$. The suspension was filtered through a bilayer of nylon to remove debris. Preparations of adult cells were filtered through 170 and $67 \mu \mathrm{m}$ pore size, whereas young cells were filtered through 67 and $30 \mu \mathrm{m}$. All preparations were centrifuged at $50 \mathrm{~g}$ for $2 \mathrm{~min}$ and washed twice with KRB containing $3 \%$ albumin (KRB-A). The final pellet was weighed and diluted to $10 \mathrm{mg}$ (wet wt) $/ \mathrm{ml} \mathrm{KRB-A}$ for incubation with hexose.

This isolation procedure yielded about $300 \mathrm{mg}$ cells/g liver, a somewhat lower yield was obtained from young than from adult liver. Light microscopic examination of the final pellet revealed round, refractile cells that were free of cell debris and excluded $95 \%$ trypan blue. Cell viability was also assessed by LDH leakage into the media and ability to convert lactate to glucose as recommended by Krebs (19).

Incubation conditions. Incubation flasks containing $2 \mathrm{ml}$ of the cell suspension were gassed with $\mathrm{O}_{2} / \mathrm{CO}_{2} 95: 5 \%$, sealed and prewarmed for $3 \mathrm{~min}$ in a $37^{\circ} \mathrm{C}$ shaking water bath. One-hundred microliters of either 200 or $800 \mathrm{mM}$ hexose containing $0.08 \mu \mathrm{Ci}$ of radiolabeled substrate were added to each flask to give a final concentration of 1 or $4 \mathrm{mM}$ sugar. Incubation intervals began with the introduction of substrate. Cell viability was maintained throughout the incubation time period.

Metabolite analysis. Changes in the concentration of radiolabeled substrates and products were measured in $500 \mu$ l samples withdrawn from the incubation flasks at 30,60 , and $90 \mathrm{~min}$ and centrifuged through a silicone layer to remove cells from the media. Media was deproteinized with sodium hydroxide and zinc sulfate (31) and the metabolites, $\left[{ }^{14} \mathrm{C}\right]$ galactose, $\left[{ }^{14} \mathrm{C}\right]$ glucose and $\left[{ }^{14} \mathrm{C}\right]$ lactate were separated by paper chromatography using ethylacetate/pyridine/water (12:5:4 by vol) as the solvent phase (29). Areas corresponding to galactose, glucose and lactate were identified by chromatographing appropriate standards. Segments corresponding to the individual sugars were cut out for radioactive counting in scintillation fluid.

In order to test whether the galactose was converted to glucose directly or whether the glucose was synthesized after glycolysis to triose phosphate, the $\%$ of $\left[6-{ }^{14} \mathrm{C}\right] \mathrm{glucose}$ was measured. After chromatographic separation of the labeled metabolites in $40 \mu \mathrm{l}$ of media from hepatocytes incubated with $4 \mathrm{mM}$ galactose, the $\left[{ }^{14} \mathrm{C}\right]$ glucose was eluted and the labeling of C- 6 was determined by isotope dilution technique. One hundred $\mathrm{mg}$ of unlabeled glucose was added as a carrier and the sample dried. The glucose was isolated as potassium gluconate (6) which was degraded by periodate oxidation (12). The resulting formaldehyde from C-6 was measured as the dimedon derivative (7).

The amount of oxidation was determined by collecting the $\mathrm{CO}_{2}$ released after $0.3 \mathrm{ml}$ of $6 \mathrm{~N}$ sulfuric acid was injected into the incubation flask. $\mathrm{CO}_{2}$ evolved was absorbed by $0.4 \mathrm{ml}$ of hyamine placed in centerwells. The radioactive content of the hyamine was assessed by placing the entire centerwell into scintillation fluid and counting it in a liquid scintillation spectrometer.

Glucose was chemically measured with a kit (33) supplied by BioDynamics, Brookfield, CT. Uptake and conversion are expressed as nmoles per $\mathrm{mg}$ cells, wet weight. Values are mean \pm S.E.M. for $n$ preparations from two to four livers. Rates are expressed as nmole $\cdot \mathrm{mg}^{-1} \cdot \mathrm{min}^{-1}$.

\section{RESULTS}

Galactose uptake. The uptake of galactose, as measured by the disappearance of the sugar from the incubation medium, is shown in Figure 1. At $1 \mathrm{mM}$, hepatocytes from both young and adult animals removed galactose at a linear rate. The suckling hepatocytes, however, utilized the sugar more rapidly, at a rate about five times faster than the adult cells, 1.08 versus $0.20 \mathrm{nmole} \cdot \mathrm{mg}^{-1}$. $\mathrm{min}^{-1}$. At $4 \mathrm{mM}$, the pattern of uptake was somewhat different from that at $1 \mathrm{mM}$ in that there was a faster uptake before $30 \mathrm{~min}$ by both groups of cells. The utilization by suckling cells at each time point studied was again about 4 -fold higher than the adult cells. These curves for $4 \mathrm{mM}$ galactose uptake differed from those found previously with perfused rat liver (2). In the perfused suckling liver, there was a $30 \mathrm{~min}$ lag before the onset of a linear rate, whereas in the perfused adult liver the curve was linear through the origin (2).

The $30 \mathrm{~min}$ uptake was also determined at 0.1 and $0.25 \mathrm{mM}$ galactose. At the lower concentration, the suckling cells extracted $8.6 \pm 0.29(n=5)$ (mean \pm S.E.M.) versus $4.47 \pm 0.17(n=8)$ nmoles/mg adult cells. At the higher concentration, the suckling value was $20.0 \pm 1.4(n=5)$ versus $5.31 \pm 0.76(n=11)$ for adult hepatocytes; thus, at all galactose concentrations studied, the suckling cells utilized galactose faster than adult cells.

Glucose output. Hepatocytes from both suckling and adult liver released glucose into the medium with more glucose appearing after incubation with galactose than in medium initially free of hexose (Fig. 2). The amount found after $30 \mathrm{~min}$ incubation of suckling hepatocytes in galactose-free medium was $76 \mathrm{nmoles} / \mathrm{mg}$ cells and was essentially the same at 60 and 90 min (Fig. 2A). Adult hepatocytes in buffer alone released only $20 \%$ of the amount formed by suckling cells by $30 \mathrm{~min}$. This increased during the subsequent $60 \mathrm{~min}$ of incubation at a rate of $0.48 \mathrm{nmoles} \cdot \mathrm{mg}^{-1}$. $\mathrm{min}^{-1}$ (Fig. 2B). In response to 1 and $4 \mathrm{mM}$ galactose, suckling cells released glucose at a linear rate of $2.35 \mathrm{nmoles} \cdot \mathrm{mg}^{-1} \cdot \mathrm{min}^{-1}$ between 30 and $90 \mathrm{~min}$ (Fig. 2A). There was no increase in glucose output when the galactose concentration was raised from 1 to 4 $\mathrm{mM}$, an observation also made during suckling liver perfusion (2). At $90 \mathrm{~min}$, the suckling cells had added 190 nmoles glucose/mg cells above the basal level (Fig. 2A).

When adult cells were incubated with galactose, there was much less glucose added to the medium than was released by suckling cells. More glucose was found in the medium of adult cells when galactose was increased from 1 to $4 \mathrm{mM}$ (Fig. $2 \mathrm{~B}$ and C). After $30 \mathrm{~min}$ incubation in $1 \mathrm{mM}$ galactose, adult cells released 16 nmoles glucose/mg cells above the basal level in galactose-free medium, compared to $55 \mathrm{nmoles} / \mathrm{mg}$ cells for suckling hepatocytes. Glucose output by adult cells in $1 \mathrm{mM}$ galactose increased linearly after $30 \mathrm{~min}$ incubation, at a rate of $0.90 \mathrm{nmoles} \cdot \mathrm{mg}^{-1}$. $\min ^{-1}$ with a net rate above the basal of 0.52 . At $90 \mathrm{~min}$, adult hepatocytes added 41 nmoles glucose/mg cells above the basal level compared to 190 for suckling cells. After correction for the basal output, adult cells incubated in $4 \mathrm{mM}$ galactose released twice as much glucose as cells incubated in $1 \mathrm{mM}$ galactose. This, however, was not sustained after $60 \mathrm{~min}$ of incubation, the slope describing the increase in medium glucose appears lower (Fig. 2C). At $90 \mathrm{~min}$, the medium of adult hepatocytes incubated in 4 $\mathrm{mM}$ galactose contained only $52 \mathrm{nmoles}$ glucose $/ \mathrm{mg}$ cells above the basal level.

Galactose conversion to glucose. To more exactly determine the relationship of galactose removed from the medium and glucose added to the medium by the cells, the conversion of $\left[1-{ }^{14} \mathrm{C}\right]-$ galactose to $\left[{ }^{14} \mathrm{Clglucose}\right.$ was studied. The results are shown in Figure 1. When suckling cells were incubated in $1 \mathrm{mM}\left[{ }^{14} \mathrm{C}\right]$ galactose, radioactive glucose appeared in the medium at a rate of $0.89 \mathrm{nmoles} \cdot \mathrm{mg}^{-1} \cdot \mathrm{min}^{-1}$, which is $82 \%$ of the rate of galactose uptake, $1.08 \mathrm{nmoles} \cdot \mathrm{mg}^{-1} \cdot \mathrm{min}^{-1}$. This value for the $\%$ conversion of $1 \mathrm{mM}$ galactose to glucose by suckling cells is the same as that observed in the perfused suckling liver (3). Adult liver cells incubated with $1 \mathrm{mM}\left[{ }^{14} \mathrm{C}\right]$ galactose converted the sugar to $\left[{ }^{14} \mathrm{C}\right]$ glucose at a rate of $0.12 \mathrm{nmoles} \cdot \mathrm{mg}^{-1} \cdot \mathrm{min}^{-1}$, which is $60 \%$ of the rate of galactose uptake, $0.20 \mathrm{nmoles} \cdot \mathrm{mg}^{-1} \cdot \mathrm{min}^{-1}$.

Figure $1 \mathrm{~B}$ shows the appearance of $\left[{ }^{19} \mathrm{C}\right]$ glucose when cells are incubated in $4 \mathrm{mM}\left[1{ }^{-14} \mathrm{C}\right]$ galactose. Labeled glucose was released into the medium at a linear rate of $0.98 \mathrm{nmoles} \cdot \mathrm{mg}^{-1} \cdot \mathrm{min}^{-1}$ for suckling and 0.14 for adult hepatocytes. These rates are essentially 


\section{$\left[1-{ }^{14} \mathrm{C}\right]$ GALACTOSE UTILIZATION AND ITS CONVERSION TO $\left[{ }^{14} \mathrm{C}\right]$ GLUCOSE}

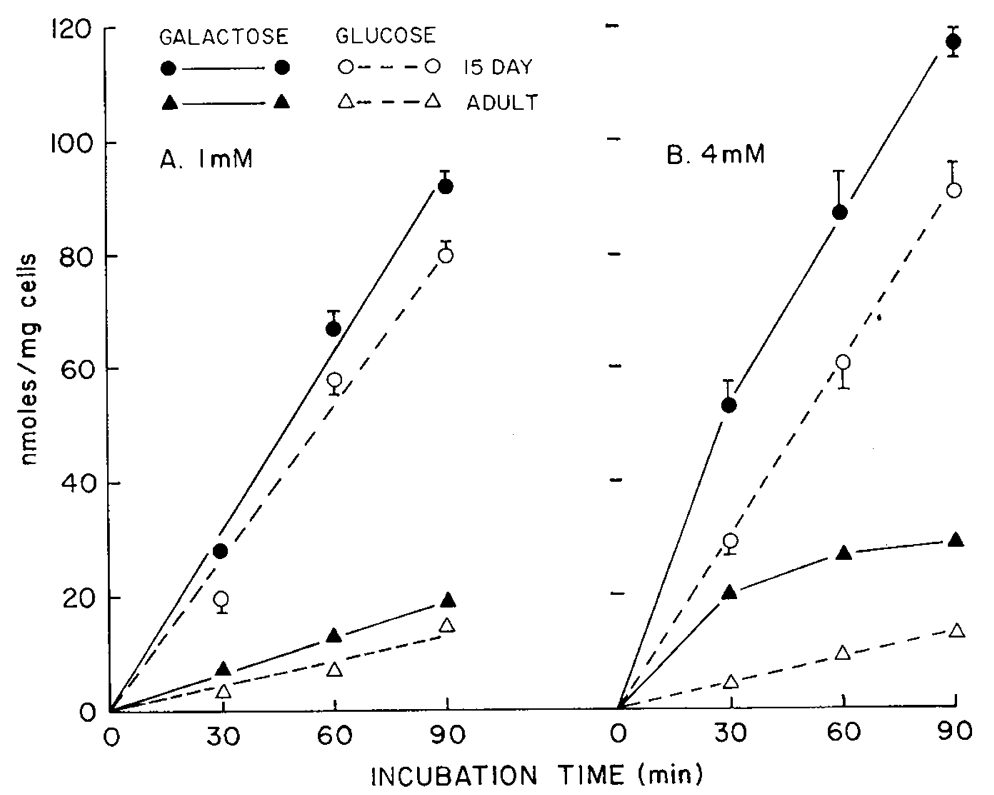

Fig. 1. $\left[1-{ }^{14} \mathrm{C}\right]$ Galactose utilization and its conversion to $\left[{ }^{14} \mathrm{C}\right]$ glucose by suckling and adult rat hepatocytes. Twenty mg (wet wt.) of hepatocytes isolated from fasted 15-day-old $(\mathrm{O}, \bullet)$ and adult $(\triangle, \Delta)$ rats were incubated with $0.08 \mu \mathrm{Ci}$ of $\left[1-{ }^{14} \mathrm{C}\right]$ galactose in $2 \mathrm{ml}$ of media containing $1 \mathrm{mM}(A)$ or $4 \mathrm{mM}(B)$ galactose. Solid symbols with solid lines indicate galactose utilization, whereas, open symbols with dashed lines indicate conversion to glucose. Aliquots of cellular suspension withdrawn at the time indicated were analyzed for metabolite levels. Experimental conditions and analyses are described in the text. Each point is the mean + S.E.M. of at least five preparations of livers pooled from two to four animals. Some S.E.s are not visible because there are less than the size of the geometric figure.

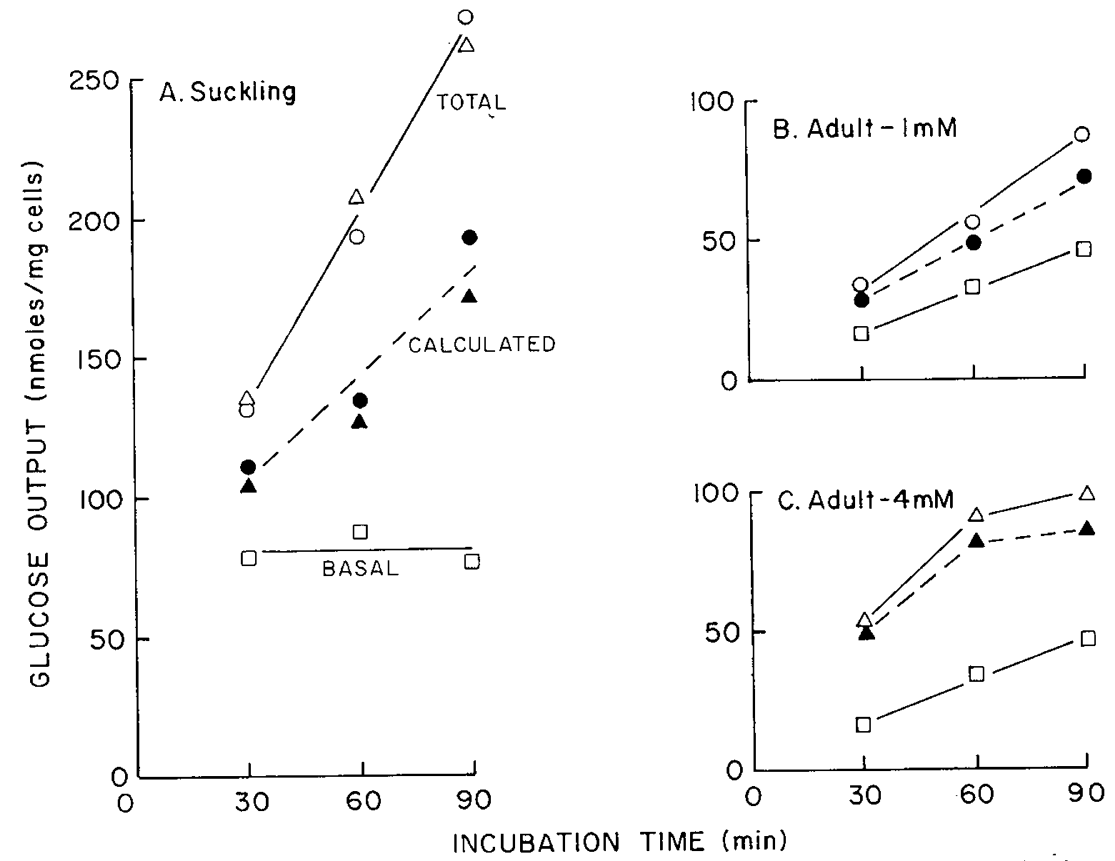

Fig. 2. Glucose output by suckling $(A)$ and adult $(B, C)$ hepatocytes incubated in the presence and absence of galactose. Liver cells were incubated without hexose to determine glucose output in the basal $(\square)$ state. Total chemical glucose was also measured in media of cells incubated with $1(O, A$ and $B)$ and $4(\triangle, A$ and $C) \mathrm{mM}$ galactose. The calculated dashed lines $(\mathbf{O}, \mathbf{\Delta})$ represent the difference between the total glucose output and the amount of $\left[{ }^{14} \mathrm{Clglucose}\right.$ output obtained from galactose conversion. Experimental conditions are given in Figure 1.

the same as those observed in Figure 1A for conversion of $1 \mathrm{mM}$ galactose. The rates of labeled glucose released are similar to the rates at which galactose is taken up after $30 \mathrm{~min}$.

Figure 3 is a plot of the correlation of $\left[{ }^{14} \mathrm{C}\right]$ galactose taken up and labeled glucose put out into the medium. These data indicate a linear relationship in both suckling and adult cells. The fact that at both galactose concentrations the adult and suckling values fit the same line suggests the same regulatory processes are operative in both young and older cells.
The recycling of $\mathrm{C}-1$ of galactose in its conversion to glucose was assessed as suggested by Van Schaftingen et al. (35) and Rognstad and Katz (23) by assaying the \% of the radioactivity in glucose which resides in the C-6 position. The results of such a study are shown in Table 1 . Only $1.5-2 \%$ of the $\left[{ }^{14} \mathrm{C}\right]$ in glucose was found in $\mathrm{C}-6$, indicating that most of the medium glucose was derived from hexose phosphate generated from galactose and not from triose phosphates. These results are similar to those observed with cells derived from adult liver (35). 
CORRELATION OF $\left[{ }^{14} \mathrm{C}\right]$ GALACTOSE UPTAKE AND CONVERSION TO GLUCOSE

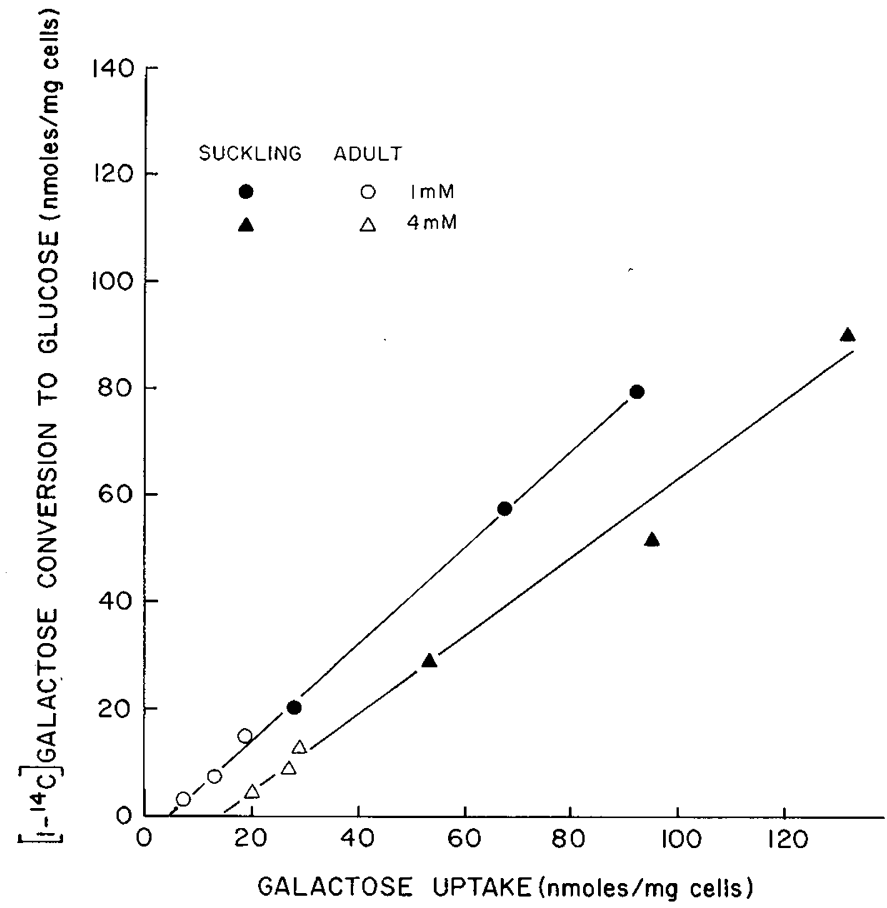

Fig. 3. Correlation of $\left[{ }^{14} \mathrm{C}\right]$ galactose uptake and conversion to glucose. Data from Figure 1 is used to depict the relationship between galactose uptake and conversion to glucose by suckling (closed symbols) and adult (open) cells. The line representing $1 \mathrm{mM}$ galactose $(O, \bullet)$ is described by the equation $\mathrm{y}=0.914 \mathrm{x}-4.18$, with a 0.999 correlation and $4 \mathrm{mM}$ galactose $(\triangle, \mathbf{\Lambda})$ by $\mathrm{y}=0.732 \mathrm{x}-10.44,0.992$ correlation.

The increment in total chemically determined glucose as shown in Figure 2 appears to be greater than the amount of glucose in the medium converted from $\left[{ }^{14} \mathrm{C}\right]$ galactose that is shown in Figure 1. If the amount of glucose in the medium accounted for by direct conversion from galactose is subtracted from the total chemically determined glucose, the dashed curves of Figure 2 are obtained. The difference between the basal glucose output values and the dashed line curves is the glucose appearing in the medium from carbon sources other than the added galactose. For the suckling cells (Fig. 2A) incubated in 1 and $4 \mathrm{mM}$ galactose for $90 \mathrm{~min}$, this is about $100 \mathrm{nmole} / \mathrm{mg}$ cells, a value slightly greater than that observed for direct conversion (Fig. 1). For adult cells (Fig. 2B and C) the amount of glucose appearing in excess of the direct galactose-glucose conversion is smaller than for suckling cells, is greater at $4 \mathrm{mM}$ galactose than at $1 \mathrm{mM}$ galactose and is actually much greater than that converted from galactose. At $30 \mathrm{~min}$ of incubation with $4 \mathrm{mM}$ galactose, for example, 4 nmoles glucose/ $\mathrm{mg}$ cells is converted from galactose (Fig. 1B) and $28 \mathrm{nmole} / \mathrm{mg}$ cells is derived from endogenous sources (Fig. 2B).

Galactose conversion to lactate. $\left[{ }^{14} \mathrm{C}\right]$ Galactose is converted to $\left[{ }^{14} \mathrm{C}\right]$ lactate when cells of either age group are incubated with galactose; media contained $3.4 \pm 0.3 \mathrm{nmole} / \mathrm{mg}$ cells and $1.6 \pm$ $0.3 / \mathrm{mg}$ cells for seven suckling and adult preparations, respectively, at $30 \mathrm{~min}$ with $1 \mathrm{mM}$ galactose. By $60 \mathrm{~min}$, the amount of $\left[{ }^{14} \mathrm{C}\right]$ lactate had doubled $(6.0 \pm 0.2, n=6)$ in media of suckling cells whereas in the adult, levels remained constant. At $4 \mathrm{mM}$ galactose the $30 \mathrm{~min}$ lactate values were $7.8 \pm 1.2 \mathrm{nmoles} / \mathrm{mg}$ cells $(n=7)$ for suckling, and $4.9 \pm 0.5(n=8)$, for adult cells. The lactate levels for suckling cells had increased to $12.1 \pm 0.7$ nmole/ mg cells $(n=6)$, by 60 min whereas levels were constant in media of adult cells. At both 1 and $4 \mathrm{mM}$ galactose, the amount converted to lactate by suckling cells was two to four times the amount converted by adult cells and this corresponded to the greater amounts of galactose taken up by suckling cells. Although the labeled lactate increased during the first $60 \mathrm{~min}$ of incubation of suckling cells, that from adult cells was at a steady-state level at the first time point, $30 \mathrm{~min}$, and did not increase after that time. The adult cells at most time points studied had converted a greater fraction of the galactose extracted from the medium to lactate. This was most pronounced at $30 \mathrm{~min}$. Results obtained with $1 \mathrm{mM}$ galactose reveal that the suckling cell converted $12 \%$ of the galactose taken up compared to $21 \%$ for adult cells. At $4 \mathrm{mM}$, values were 15 and $24 \%$ for suckling and adult cells respectively.

Galactose oxidation to $\left[{ }^{14} \mathrm{CO}_{2}\right]$. The amount of $\left[1-{ }^{14} \mathrm{C}\right]$ galactose metabolized to $\left[{ }^{14} \mathrm{CO}_{2}\right]$ is shown in Figure 4. Suckling hepatocytes metabolized more galactose to $\left[{ }^{14} \mathrm{CO}_{2}\right]$ than adult cells. The rate of oxidation of both 1 and $4 \mathrm{mM}$ galactose was the same in the adult cells but the younger cells increased their oxidation when the substrate was increased from 1 to $4 \mathrm{mM}$. For $1 \mathrm{mM}$ galactose, the oxidation rate, $0.10 \mathrm{nmole} \cdot \mathrm{mg}^{-1} \cdot \mathrm{min}^{-1}$, was $9 \%$ of the galactose uptake rate in suckling cells whereas the rate in adult cells, $0.04 \mathrm{nmole} \cdot \mathrm{mg}^{-1} \cdot \mathrm{min}^{-1}$, was $25 \%$ of the sugar's rate of uptake.

$\left[1-{ }^{14} \mathrm{C}\right] \mathrm{Galactose}$ oxidation to $\left[{ }^{14} \mathrm{CO}_{2}\right]$ was also compared to [1${ }^{14} \mathrm{C}$ glucose oxidation by suckling and adult hepatocytes. Figure 4 shows that the oxidation of $1 \mathrm{mM}$ galactose is about three times more rapid than that of glucose in both suckling and adult hepatocytes. In the suckling cells, $4 \mathrm{mM}$ galactose is also more rapidly oxidized than glucose; but in adult cells, this is not the case.

Because the differences in galactose conversion to metabolites by hepatocytes of different ages appeared to reflect the differences in removal of galactose from the medium, we examined glucose removal to ascertain if the difference in galactose and glucose oxidation could be explained in this way. Such appeared to be the case. Suckling hepatocytes incubated for $30 \mathrm{~min}$ in $1 \mathrm{mM}$ glucose had a net removal of $9.5 \pm 2.0$ nmole $/ \mathrm{mg}$ cells $(n=5)$, compared to $27.7 \pm 2.8(n=5)$, for galactose. Additionally, no further removal of glucose from the medium occurred over an ensuing 60 min incubation interval while galactose was continuously extracted. The same differences in removal of the hexoses were observed at $4 \mathrm{mM}$ where the younger cells at $30 \mathrm{~min}$ removed $30.7 \pm 5.6$ nmoles glucose $/ \mathrm{mg}$ cells $(n=5)$ and $52.7 \pm 3.9$ nmoles galactose $/ \mathrm{mg}$ cells for $n=7$ preparation. Although galactose removal was sustained after $30 \mathrm{~min}$, net glucose removal was not.

Comparison of $\left[1-{ }^{14} \mathrm{C}\right]$ galactose and $\left[2-{ }^{14} \mathrm{C}\right]$ galactose oxidation. Because the metabolism of galactose to galactonate has been shown in rat liver (21) and the subsequent decarboxylation of the hexonic acid to pentose has been proposed (11), evidence was sought for such a sequence by comparing the oxidation of $\mathrm{C}-1$ and $\mathrm{C}-2$ labeled sugar. The rationale for this was that preferential loss of the first carbon as $\left[{ }^{14} \mathrm{CO}_{2}\right]$ might be observed. Figure 5 shows the oxidation of $4 \mathrm{mM}$ galactose by suckling and adult liver cells where $\left[{ }^{14} \mathrm{CO}_{2}\right]$ was derived from $\left[1{ }^{14} \mathrm{C}\right]$ galactose at a rate 3 times that from $\left[2-{ }^{14} \mathrm{C}\right]$ galactose. Because the major pathway of galactose metabolism to $\left[{ }^{14} \mathrm{CO}_{2}\right]$ is via prior conversion to glucose6-phosphate, the oxidation of glucose labeled in the same carbon positions was also examined. A similar ratio is obtained for $\left[{ }^{14} \mathrm{CO}_{2}\right]$

Table 1. Radioactivity in C-6 of glucose present in media from hepatocytes incubated with $4 \mathrm{mM}\left[1-{ }^{14} \mathrm{C}\right]$ galactose ${ }^{1}$

\begin{tabular}{|c|c|c|}
\hline $\begin{array}{l}\text { Incubation } \\
\text { time (min) }\end{array}$ & $\begin{array}{c}10^{-3} \times\left[{ }^{14} \mathrm{C}\right] \text { in glucose } \\
(\mathrm{cpm} / \mathrm{ml})\end{array}$ & $\begin{array}{c}{\left[{ }^{14} \mathrm{C}\right] \text { in } \mathrm{C}-6 \text { of glucose }} \\
\left(\% \text { of total }\left[{ }^{14} \mathrm{C}\right] \text { in }\right. \\
\text { glucose })\end{array}$ \\
\hline 30 & 6.3 & 1.6 \\
\hline 60 & 11.0 & 1.5 \\
\hline 90 & 19.3 & 2.1 \\
\hline
\end{tabular}

${ }^{1}$ Hepatocytes, isolated from fasted 14-day-old suckling rat livers, were incubated with $4 \mathrm{mM}\left[1-{ }^{14} \mathrm{C}\right]$ galactose. Aliquots, withdrawn at timed intervals, were centrifuged through silicone oil to remove cellular matter and the media were analyzed for $\left[6{ }^{14} \mathrm{C}\right]$ glucose content. The analytic method is described in the text. Data are the average of duplicate assays. 


\section{$\left[1-{ }^{14} \mathrm{C}\right]$ GALACTOSE AND $\left[1-{ }^{14} \mathrm{C}\right]$ GLUCOSE OXIDATION}

\section{A. SUCKLING}

$\operatorname{lmM} 4 \mathrm{mM}$
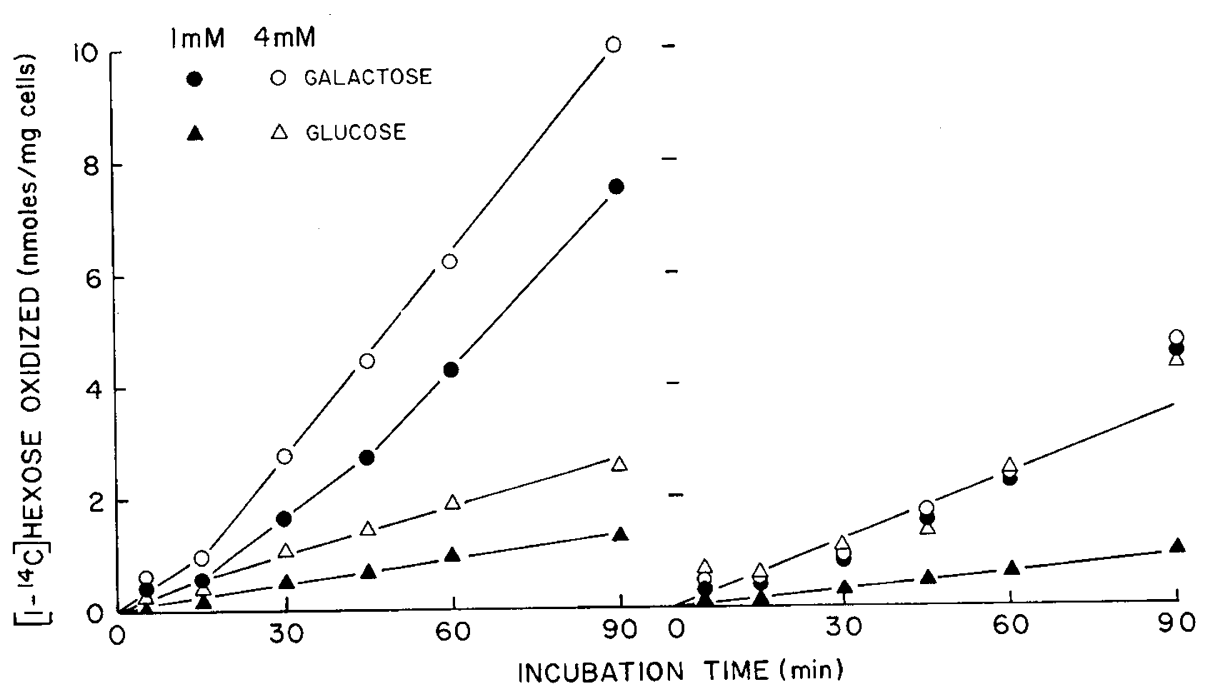

B. ADULT

Fig. 4. $\left[1{ }^{14} \mathrm{C}\right]$ Galactose and $\left[1-{ }^{14} \mathrm{C}\right]$ glucose oxidation by suckling $(A)$ and adult $(B)$ hepatocytes. $\left[{ }^{14} \mathrm{CO}_{2}\right]$ production during incubation with galactose $(O,-)$ and glucose $(\triangle, A)$ at concentrations of $1 \mathrm{mM}$ (solid symbols) and $4 \mathrm{mM}$ (open) are graphed with respect to time interval. Each point is the mean of $\left[{ }^{14} \mathrm{CO}_{2}\right]$ collected for $\mathrm{n}$ varied between 5 and 25 . The S.E. was less than $10 \%$ of the mean value. Experimental conditions are given in Figure 1 and the procedures are detailed in the text.

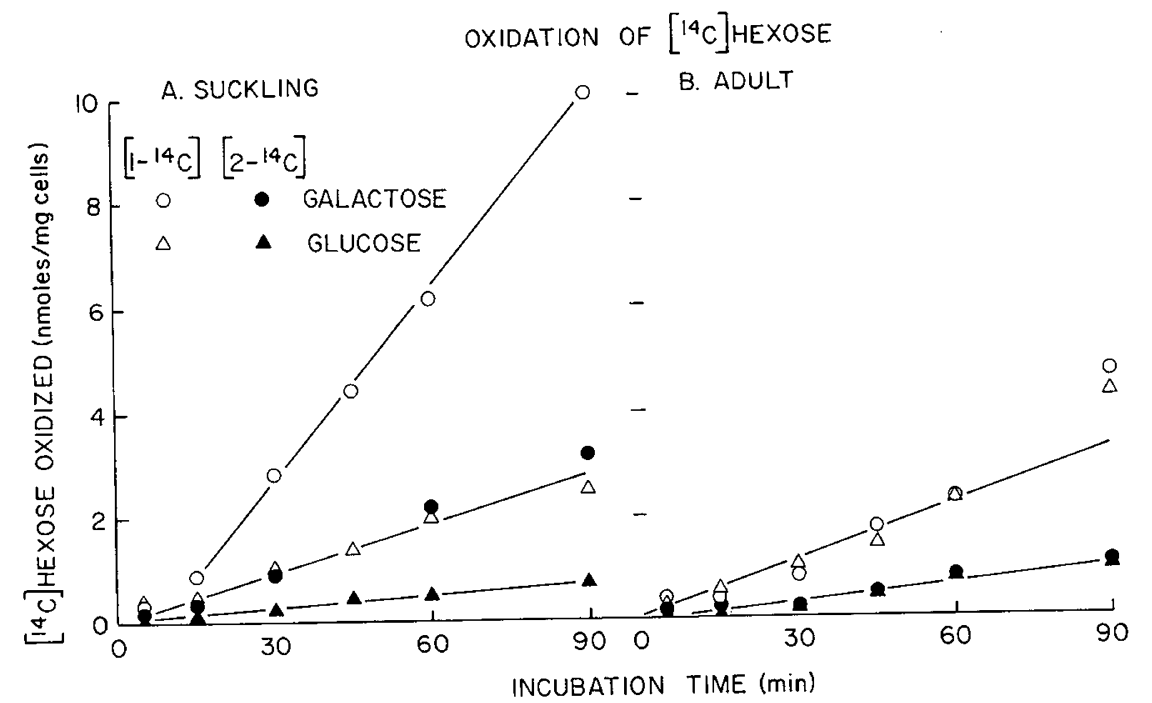

Fig. 5. Oxidation of $\left[{ }^{14} \mathrm{C}\right]$ hexose by suckling $(a)$ and adult $(b)$ heptocytes. Galactose (circles) or glucose (triangles) labeled in the first position (open symbols) and second position (closed) was incubated with rat hepatocytes. The concentration of either hexose was $4 \mathrm{mM}$. Each point is the mean of $\left[{ }^{14} \mathrm{CO}_{2}\right]$ collected from 3-25 The S.E. was less than $10 \%$ of the mean value. Experimental conditions are given in Figure 1.

yield from the $\mathrm{C}-1$ and $\mathrm{C}-2$ labeled glucose; thus, at $4 \mathrm{mM}$ galactose there was no indication for operation of a direct oxidative pathway of galactose metabolism with preferential loss of carbon one.

Galactose metabolism with development. Results for galactose uptake and conversion to glucose, lactate and $\mathrm{CO}_{2}$ by hepatocytes of various age animals incubated for $30 \mathrm{~min}$ in $4 \mathrm{~mm}$ galactose are shown in Figure 6. Galactose removal and subsequent metabolism is the same at 7 days of age as it is for the 14-day-old suckling cells. After 14 days there is an almost linear decrease in galactose removal with a parallel decrease in galactose conversion to glucose. The decrease in conversion of galactose to lactate and $\mathrm{CO}_{2}$, observed between 14 days of age and the adult is not as marked as that of removal and conversion to glucose.

$\left.{ }^{14} \mathrm{C}\right]$ Balance. Table 2 shows the isotopic balance in the medium of hepatocytes incubated with $\left[1-{ }^{14} \mathrm{C}\right]$ galactose. At $1 \mathrm{mM}$, up to $92 \%$ of the labeled sugar was removed by the suckling cells in the 90 min incubation period but only $19 \%$ by adult hepatocytes. The conversion to glucose, lactate and $\mathrm{CO}_{2}$ accounted for most of the $\left[{ }^{14} \mathrm{Clgalactose}\right.$ removed from the medium by the suckling cells. After $90 \mathrm{~min}$ incubation in $4 \mathrm{mM}$ galactose, $33 \%$ of added galactose was removed by suckling cells but only $7 \%$ by adult cells. At this higher concentration, there was a large unaccounted difference in total isotopic recovery which in the suckling cells was about $25 \%$ and in adult about 50\%. This can also be seen in Figure 6 where the discrepancy between galactose removed and the sum of metabolites assayed increases with age. In similar studies using adult hepatocytes with gluconeogenic precursors such as lactate, Katz et al. (17) found large amounts of label located in the amino acid pools, products not assayed in the present studies. 


\section{DISCUSSION}

There appear to be marked differences in the disposition of galactose by hepatocytes from 14-day-old suckling rats and cells from adult livers. Young cells remove galactose from the medium at a rate several-fold faster than older cells. This is accompanied by a parallel increase in galactose conversion to glucose, is reflected in metabolism to lactate, and oxidation to $\mathrm{CO}_{2}$ and a decreased conversion to other undetermined metabolites. The present data amplify our previous findings (27) employing a liver brei from young animals and the observations of Fukushima et al. (14), that primary hepatocyte cultures, when first initiated from young rat liver, utilize greater amounts of galactose over a $24 \mathrm{~h}$ period than cells from adult liver.

Our present findings, in some ways, are similar to those we reported in liver perfusion studies and, in other ways, different. As with hepatocyte incubations, 15-day-old suckling livers per-

GALACTOSE METABOLISM BY HEPATOCYTES OF SUCKLING AND ADULT RATS

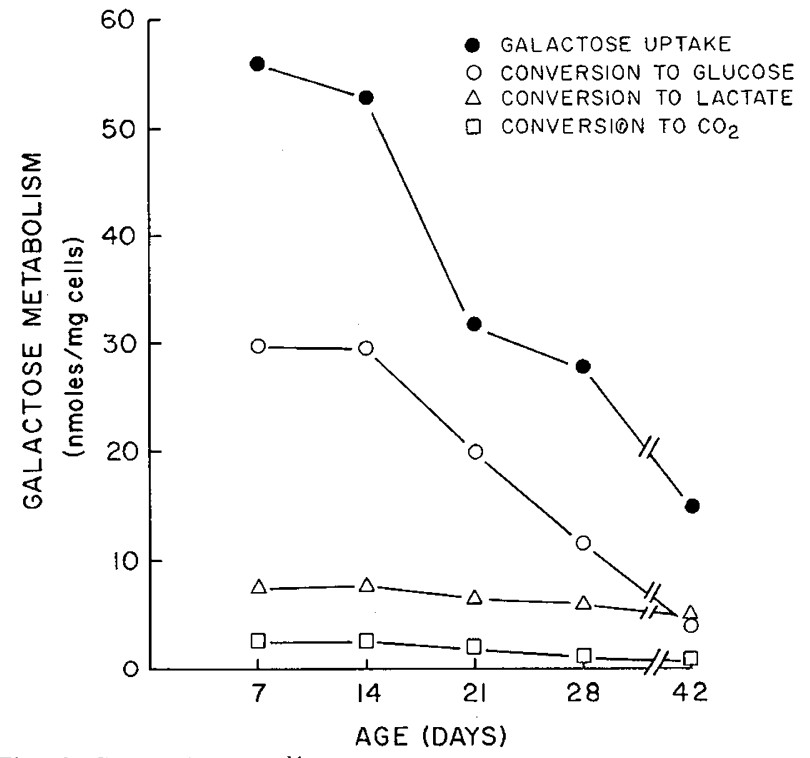

Fig. 6. Comparison of $\left[{ }^{14} \mathrm{C}\right]$ galactose metabolism during postnatal development. The galactose uptake $(\bullet)$ and its conversion to glucose $(\bigcirc)$ lactate $(\triangle)$ and oxidation to $\mathrm{CO}_{2}(\square)$ are given for the ages indicated. Each point represents the mean of duplicate assays of hepatocyte preparations from two to four pooled livers. Experimental conditions are the same as those given in Figure 1. fused with $4 \mathrm{mM}$ galactose took up more substrate and put out glucose at a faster rate than the adult (2). A detailed comparison of the results of hepatocyte incubation and whole liver perfusion can be made from our more extensive results reported for suckling liver perfusion (3). In both types of experiments, about $80 \%$ of the $\left[{ }^{14} \mathrm{C}\right]$ galactose taken up by suckling tissue was converted to $\left[{ }^{14} \mathrm{C}\right]$ glucose. A difference between the results obtained with the two techniques can be found in the patterns of galactose uptake. When $4 \mathrm{mM}$ galactose was perfused, there was an initial $35 \mathrm{~min}$ lag in uptake before a linear rate was established (2), whereas with hepatocytes, there was an initial surge of uptake before the linear rate was observed.

Another disparity observed in the results from suckling hepatocyte preparations and liver perfusion relates to the effect of galactose on total glucose output. We reported (3) that the total chemical glucose put out during galactose perfusion was less than the sum of basal output when only buffer was circulated and the $\left[{ }^{14} \mathrm{C}\right]$ glucose derived from labeled galactose, concluding that galactose suppressed endogenous glucose production of other precursors. Just the opposite was found, however, with isolated cells (Fig. 2), which produce much more total glucose than the sum of that converted from galactose and the basal glucose production, leading to the presumption that galactose stimulates gluconeogenesis from endogenous precursors. Similar observations have been reported by Kleigman et al. (18) who found greater endogenous glucose production after enteric galactose administration to newborn puppies than for those fed glucose. These observations deserve further study with radioactive glucose precursors such as lactate.

The higher galactose utilization rate observed for young liver reflects higher levels of specific activities of the galactose metabolizing enzymes-galactokinase, galactose-1-phosphate uridyltransferase, and UDPgalactose-4-epimerase-in the suckling period and parallels the fall to lower enzyme levels over the same time period in which the utilization rate falls (Fig. 6). This is also the period when the rat pups are decreasing milk intake and beginning to eat lab chow, thus diminishing the amount of galactose in the diet. Our animals are fully weaned at 21 days. Attempts to prevent the enzyme specific activities from falling by weaning onto high galactose diets have not succeeded (10) and high galactose in the medium could not prevent the fall in galactose utilization by suckling hepatocytes cultured for several days (14) suggesting that dietary galactose levels are not responsible for the changes. We are in the process of examining the role of diet on total hepatocyte galactose utilization.

Whether there are other factors besides hyperactivity of the Leloir pathway enzymes, which are responsible for the high galactose utilization by young cells, deserves comment especially in view of the increased potential for gluconeogenesis by perfused

Table 2. Media isotope balance (\% of galactose added) ${ }^{1}$

\begin{tabular}{|c|c|c|c|c|c|c|c|}
\hline $\begin{array}{l}\text { Substrate } \\
\text { concentra- } \\
\text { tion (mM) } \\
\end{array}$ & & $\begin{array}{l}\text { Incubation time } \\
\text { (min) }\end{array}$ & Galactose uptake & $\begin{array}{l}\text { Conversion to } \\
{\left[{ }^{14} \mathrm{C}\right] \text { glucose }}\end{array}$ & $\begin{array}{c}\text { Conversion to } \\
{\left[{ }^{14} \mathrm{C}\right] \text { lactate }}\end{array}$ & $\begin{array}{l}\text { Oxidation to } \\
{\left[{ }^{14} \mathrm{CO}_{2}\right]}\end{array}$ & $\begin{array}{c}\text { (Unaccounted } \\
\text { difference from } \\
100 \%) \\
\end{array}$ \\
\hline \multirow[t]{6}{*}{1} & $\mathbf{S}$ & 30 & 27 & 20 & 3.4 & 1.7 & 1.9 \\
\hline & & 60 & 67 & 58 & 6.0 & 4.3 & -1.3 \\
\hline & & 90 & 92 & 80 & 5.7 & 7.5 & -1.9 \\
\hline & A & 30 & 7 & 3 & 1.6 & 0.9 & 1.5 \\
\hline & & 60 & 13 & 7 & 1.5 & 2.2 & 2.3 \\
\hline & & 90 & 19 & 15 & 1.3 & 4.4 & -1.7 \\
\hline \multirow[t]{6}{*}{4} & $\mathrm{~S}$ & 30 & 13 & 7 & 2.0 & 0.7 & 3.3 \\
\hline & & 60 & 24 & 13 & 3.1 & 1.6 & 6.3 \\
\hline & & 90 & 33 & 23 & 3.5 & 2.5 & 4.0 \\
\hline & A & 30 & 5 & 1 & 1.2 & 0.2 & 2.6 \\
\hline & & 60 & 7 & 2 & 1.2 & 0.6 & 2.2 \\
\hline & & 90 & 7 & 1 & 1.2 & 1.2 & 3.6 \\
\hline
\end{tabular}

${ }^{1}$ Isolated hepatocytes from fasted suckling (S) and adult (A) rats were incubated with $0.8 \mu \mathrm{Ci}\left[1-{ }^{14} \mathrm{C}\right]$ galactose. Media withdrawn at timed intervals were analyzed for the radiolabeled metabolites listed. Experimental conditions are detailed in the text. Percentages were calculated from mean values with S.E. less than $10 \%$ of the mean for $n$ varied between 4 and 14 preparations. 
liver and hepatocytes of suckling rats (1). Indeed, the basal level of glucose output from suckling cells in our own studies was much higher than from adult cells (Fig. 2) and the rate of galactose conversion to glucose several-fold higher in suckling tissue (Fig. 1). Perhaps the hormonal and other factors responsible for increased gluconeogenesis from lactate are also operative with regard to galactose, thus contributing to the high rate of galactose extracted from the incubation medium. Simkins et al. (30) have shown that glucocorticoids enhance the formation of glucose from galactose by fetal rat liver explants in organ culture.

Van Schaftinger and his colleagues (35), however, have shown that there is little or no recycling of label in C-1 of galactose to C6 in fasted adult hepatocytes and we have shown this to be the case in suckling cells. Katz et al. (16) have pointed out that tritiated galactose in the C-2 position loses $80 \%$ of its label when converted to glucose by adult hepatocytes. Both observations are consistent with galactose metabolism to fructose-6-phosphate followed by conversion back to glucose and little recycling from breakdown to triose phosphate. The presentation of increased amounts of glucose-6-phosphate via the Leloir pathway plus the increase in glucose-6-phosphatase activity in the suckling period (8) would explain the increased conversion to medium glucose. Vernon and Walker (36) have reported that there is little or no recycling of glucose via the Cori cycle in the intact suckling rat.

The use of isolated hepatocytes permitted an examination of the oxidation of $\left[1-{ }^{14} \mathrm{C}\right]$ galactose to $\left[{ }^{14} \mathrm{CO}_{2}\right]$, which could not be done in our liver perfusion apparatus. The results indicate that metabolism of galactose to $\mathrm{CO}_{2}$ is not nearly as extensive as conversion to glucose nor, indeed, the major metabolic fate of galactose in short term studies. In vivo studies in normal man have shown that within half an hour after injection of radioactive galactose, more than $50 \%$ of the label is present in the circulating glucose pool with much less conversion to $\mathrm{CO}_{2}$ (24). It appears that under normal circumstances the labeled $\mathrm{CO}_{2}$ from galactose arises from the oxidation of glucose derived from galactose (25). When, however, the Leloir pathway is defective in humans (26) or when rats are exposed to high galactose diets (21), the oxidation product, galactonate, is formed which Cuatrecasas and Segal (11) indicated could be decarboxylated to $\mathrm{CO}_{2}$ and pentose. A preferential loss of $\mathrm{C}-1$ of radioactive galactose compared to $\mathrm{C}-2$ has been demonstrated in humans lacking galactose-1-phosphate uridyltransferase (26); therefore, preferential oxidation was examined in the present studies to determine if the higher oxidation rate of suckling cells compared to adult cells could be explained by this mechanism. This was found not to be the case when $4 \mathrm{mM}$ galactose was used as the substrate. There was a difference in the rate of oxidation of C-1 and C-2 labeled galactose but the relative difference was similar in suckling and adult cells. Our data also indicated that the difference in $\left[{ }^{1} \mathrm{CO}_{2}\right]$ yield from the $\mathrm{C}-1$ and $\mathrm{C}$ 2 labeled galactose was paralleled by the same difference in the yield from $\mathrm{C}-1$ and $\mathrm{C}-2$ labeled glucose, suggesting that a direct oxidative pathway for galactose metabolism was not present in the hepatocyte. This is not surprising in view of the very high $\mathrm{Km}$ for the system responsible for galactose conversion to galactonate (21).

The rate of labeled galactose conversion to $\left[{ }^{14} \mathrm{CO}_{2}\right]$ was found to be much higher than that of labeled glucose. It should be pointed out, however, that at the substrate levels used we found very little net uptake of glucose compared to that of galactose. Katz et al. (16) have indicated that there is extensive recycling of glucose and glucose-6-phosphate at the low glucose concentrations we used and that in view of the low net of uptake one cannot really calculate the amount of glucose oxidized nor truly compare the relative rates of galactose and glucose oxidation.

From accumulating data, it seems clear that the ability of liver to metabolize galactose is optimal in the suckling period when galactose is a prime nutrient and there is a greater need to efficiently utilize the sugar. There are indications, however, that galactose may have other important aspects than providing usable calories. Sparks and Glinsman (32) have shown that galactose perfusion of liver augments glycogen synthetase activity and other reports have indicated that galactose may be a factor in regulation of glucokinase (37). Our present finding that galactose augments gluconeogenesis adds another important function to this growing list.

\section{REFERENCES AND NOTES}

1. Beaudry, M., Chiasson, J. and Exton, J.: Gluconeogenesis in the suckling rat Am. J. Physiol., 2: E175 (1977).

2. Berman, W. F., Rogers, S. R., Bautista, J., and Segal, S.: Galactose and glucose metabolism in the isolated perfused suckling and adult rat liver. Metabolism, 27: 1721 (1978)

3. Berman, W., Rogers, S., Bautista, J., and Segal, S.: Galactose metabolism in isolated perfused suckling rat liver. Am. J. Physiol., 236: E633 (1979)

4. Berry, M. N. and Friend, D. S.: High-yield preparation of isolated rat liver parenchymal cells. J. Cell Biol., 43: 506 (1969).

5. Bertoli, D. and Segal, S.: Developmental aspects and some characteristics of mammalian galactose-1-phosphate uridyltransferase. J. Biol. Chem., 241: 4023 (1966).

6. Blair, A. and Segal, S.: The isolation of blood glucose as potassium gluconate. J. Lab. Clin. Med., 55: 959 (1960).

7. Bloom, B.: The simultaneous determination of $\mathrm{C}^{14}$ and $\mathrm{H}^{3}$ in the terminal groups of glucose. Anal. Biochem., 3: 85 (1962)

8. Burch, H. B., Lowry, O. H., Kuhlman, A. M., Skerjance, J., Daimant, E. J., Lowry, S. R., and Von Dippe, P.: Changes in patterns of enzymes of carbohydrate metabolism in developing rat liver. J. Biol. Chem., 238: 2267 (1963).

9. Cohn, R. and Segal, S.: Some characteristics and developmental aspects of rat uridine diphosphogalactose 4-epimerase. Biochim. Biophys. Acta, 171: 333 (1969).

10. Cuatrecasas, P. and Segal, S.: Mammalian galactokinase: developmental and adaptive characteristics in the rat liver. J. Biol. Chem., 240: 2382 (1965).

11. Cuatrecasas, P. and Segal, S.: Galactose conversion to d-xylulose: an alternate route of galactose metabolism. Science, 153: 549 (1966)

12. Eisenberg, F. Jr.,: The degradation of isotopically-labeled glucose via periodate oxidation of gluconate. J. Am. Chem. Soc., 76: 5152 (1954).

13. Exton, J. H. and Park, C. R.: Control of gluconeogenesis in liver I. General features of gluconeogenesis in the perfused livers of rats. J. Biol. Chem., 242: 2622 (1967).

14. Fukushima, N., Cohen-Khallas, M., and Kalant, N.: Galactose and glucose metabolism by cultured hepatocytes: responsiveness to insulin and the effect of age. Dev. Biol., 84: 359 (1981).

15. Hems, R., Ross, B. D., Berry, M. N., and Krebs, H. A.: Gluconeogenesis in the perfused rat liver. Biochem. J., 101: 284 (1966).

16. Katz, J., Golden, S., and Wals, P.: Glycogen synthesis by rat hepatocytes. Biochem. J., 180: 389 (1979)

17. Katz, J., Wals, P. A., and Rognstad, R.: Glucose phosphorylation, glucose-6phosphatase, and recycling in rat hepatocytes. J. Biol. Chem., 253: 4530 (1979).

18. Kliegman, R. M., Miettinen, E. L., Kalhan, S. C., and Adam, P. A. J.: The effect of enteric galactose on neonatal canine carbohydrate metabolism. Metabolism, 30: 1109 (1981).

19. Krebs, H. A., Cornwell, N. W., Lund, P., and Hems, R.: In: Regulation of Hepatic Metabolism Ed: F. Lundquist, and N. Tygstrup, pp. 727-748 (New York, Academic Press, 1974)

20. Mortimore, G. E.: Effect of insulin on potassium transfer in isolated rat liver. Am. J. Physiol., 200: 1315 (1961).

21. Rancour, N. J., Hawkins, E., and Wells, W. W.: Galactose oxidation in liver. Arch. Biochem. Biophys., 193: 232 (1979).

22. Rogers, S. and Segal, S.: Changing activities of galactose-metabolizing enzymes during perfusion of suckling-rat liver. Am. J. Physiol., 240: E333 (1981).

23. Rognstad, R. and Katz, J.: Effects of hormones and of ethanol on the fructose 6$\mathrm{P}$-fructose 1, 6- $\mathrm{P}_{2}$ futile cycle during gluconeogenesis in the liver. Arch. Biochem. Biophys., 177: 337 (1976).

24. Segal, S. and Blair, A.: Some observations on the metabolism of d-galactose in normal man. J. Clin. Invest., 40: 2016 (1961).

25. Segal, S., Blair, A., and Roth, H.: The metabolism of galactose by patients with congenital galactosemia. Am. J. Med., 38: 62 (1965).

26. Segal, $S$. and Cuatrecasàs, $P$.: The oxidation of $C^{14}$ galactose by patients with congenital galactosemia: evidence for a direct oxidative pathway. Am. J. Med., 44: 340 (1968).

27. Segal, S., Roth, H., and Bertoli, D.: Galactose metabolism by rat liver tissue influence of age. Science, 142: 1311 (1963).

28. Seglen, P. O.: Preparation of rat liver cells: III. Enzymatic requirements for tissue dispersion. Exp. Cell Res., 82: 391 (1973)

29. Shih, V. E.: Laboratory Techniques for the Detection of Hereditary Metabolic Disorders. p. 83. (Cleveland, CRC Press, 1973).

30. Simkins, R. A., Eisen, H., Sparks, J. W., and Glinsmann, W.: Development of gluconeogenesis from galactose by fetal rat liver explants in organ culture. Dev. Biol., 66: 353 (1978).

31. Somogyi, M.: Determination of blood sugar. J. Biol. Chem., 160: 69 (1945)

32. Sparks, J. W., Lynch, A., and Glinsmann, W. H.: Regulation of rat liver glycogen synthesis and activities of glycogen cycle enzymes by glucose and galactose. Metabolism, 25: 47 (1976)

33. Trinder, P.: Determination of glucose in blood using glucose oxidase with an alternative oxygen acceptor. Ann. Clin. Biochem., 6: 24 (1969).

34. Tygstrup, N.: Effect of sites for blood sampling in determination of the galactose 
elimination capacity. Scand. J. Clin. Invest., 18: 118 (1966).

35. Van Schaftingen, E., Hue, L., and Hers, H.-G.: Control of the fructose-6phosphate/fructose 1, 6-bisphosphate cycle in isolated hepatocytes by glucose and glucagon. Biochem. J., 192: 887 (1980)

36. Vernon, R. G. and Walker, D. G.: Glucose metabolism in the developing rat studies in vivo. Biochem. J., 127: 521 (1972).

37. Wakelam, M. J., Allen, M. B., and Walker, D. G.: Factors that prevent the premature appearance of glucokinase in neonatal rat liver. Biochem. J., 186: 817 (1980).

38. Walli, A. K. and Schimassek, H.: In: Use of Isolated Liver Cells and Kidney Tubules in Metabolic Studies Ed: J. M. Tager, H. D. Soling, and J. R. Williamson, pp. 426-429. American Elsevier Publishing Co., Inc., (New York
1976).

39. Woods, H., Eggleston, L., and Krebs, H.: The cause of hepatic accumulation of fructose-1-phosphate on fructose loading. Biochem. J., 119: 501 (1970).

40. Requests for reprints should be addressed to: Dr. Stanton Segal, Division of Metabolism, Children's Hospital of Philadelphia, 34th St. \& Civic Center Blvd., Philadelphia, PA. 19104.

41. This research was supported by National Institutes of Health Grant HD-08536.

42. Received for publication July $29,1982$.

43. Accepted for publication November 5, 1982. 